\title{
Sexual and prevention practices in men who have sex with men in the era of combination HIV prevention: results from the Presse Gays et Lesbiennes survey, France, 2011
}

A Velter (a.velter@invs.sante.fr) ${ }^{1}$, L Saboni ${ }^{1}$, C Sommen $^{1}$, P Bernillon ${ }^{1}$, N Bajos $^{2}$, C Semaille $^{1}$

1. Institut de Veille Sanitaire, Saint Maurice, France

2. CESP-Inserm U1018, Le Kremlin-Bicêtre, France Université Paris-Sud, Faculté de Médecine, Le Kremlin-Bicêtre, France

Velter A, Saboni L, Sommen C, Bernillon P, Bajos N, Semaille C. Sexual and prevention practices in men who have sex with men in the era of combination HIV prevention: results from the Presse Gays et Lesbiennes survey, France, 2011. Euro Surveill. 2015;20(14):pii=21090. Available online: http://www.eurosurveillance. org/ViewArticle.aspx?Articleld=21090

Article submitted on 28 August 2014 / published on 09 April 2015

To better understand the diversity of practices and behaviours to prevent HIV with casual partners, data from a large convenience sample of men who have sex with men (MSM) in France were categorised into different prevention profiles: no anal intercourse, consistent condom use during anal intercourse, risk-reduction practices (serosorting, seropositioning) and no discernible prevention practice (NDPP). Categories were applied to HIV-positive respondents with controlled $(\mathrm{Cl} ; \mathrm{n}=672)$ and uncontrolled infection (UI; $n=596)$, HIV-negative $(n=4,734)$ and untested respondents $(n=663)$. Consistent condom use was reported by $22 \%$ $(n=148)$ of HIV-positive-CI respondents, $13 \%(n=79)$ of HIV-positives UI, $55 \%(2,603)$ of HIV-negatives, and $50 \%(n=329)$ of untested ( $p<0.001)$. Corresponding figures for NDPP were $45 \%(n=304), 55 \%(n=327), 21 \%$ $(n=984)$ and $34 \%(n=227)(p<0.001)$. Logistic regressions showed that, regardless of respondents' serostatus, NDPP was associated with regularly frequenting dating websites, drug use, exposure to sperm during oral sex, and with HIV diagnosis after 2000 for HIVpositive respondents $(\mathrm{Cl}$ and $\mathrm{UI})$, with age $<30$ years for HIV-positive-CI, and with low education for HIVnegatives. Risk-taking remains high, despite implementation of risk-reduction practices. A global health approach should be central to prevention programmes for MSM, to include target behavioural intervention, promotion of condom use, and encouragement of regular HIV testing and early initiation of ART.

\section{Introduction}

Sex between men remains the most frequent mode of HIV transmission in men in North America, Australia and western Europe [1]. Newly diagnosed HIV infections among men who have sex with men (MSM) increased in Europe by 33\% between 2004 and 2013 [2]. Similar trends have been observed in France, where MSM are increasingly predominant among newly diagnosed cases [3]. Incidence in MSM in France is 200 times higher than in the French heterosexual population [4].

Studies conducted since the epidemic began have shown how MSM have profoundly changed their sexual behaviours by implementing different strategies to manage the risk of HIV transmission. During the second half of the 1980s, MSM reduced their number of partners and began condom use on a widespread basis. During the 1990s, alternative strategies to systematic condom use emerged, such as negotiated safety with a steady partner [5]. Since 2000 , condom use has fallen consistently regardless of partner type and HIV serostatus [5]. Simultaneously, alternative risk-reduction strategies have materialised under the umbrella term 'seroadaptation' $[6,7]$. These strategies include serosorting (engaging in unprotected anal intercourse (UAI) with partners of the same HIV status), seropositioning (HIV-positive men engaging in receptive and HIV-negative men in insertive UAI) and selective avoidance of anal intercourse.

In the meantime, the effectiveness of antiretroviral treatment has contributed to the medicalisation of prevention [8], although more evidence is needed on the efficacy of treatment as prevention among MSM [9]. More frequent testing among sexually active MSM [10] might shorten the delay between contamination and diagnosis [11], so that treatment could start as early as possible [9]. Furthermore, the availability of preexposure prophylaxis (PreP) might reduce the risk of transmission in uninfected people [12]. In this context, preventive-behavioural and biomedical approaches need to complement each other [13].

In this article, we first describe the prevalence of sexual preventive behaviours by categorising the different risk-reduction practices according to respondents' 


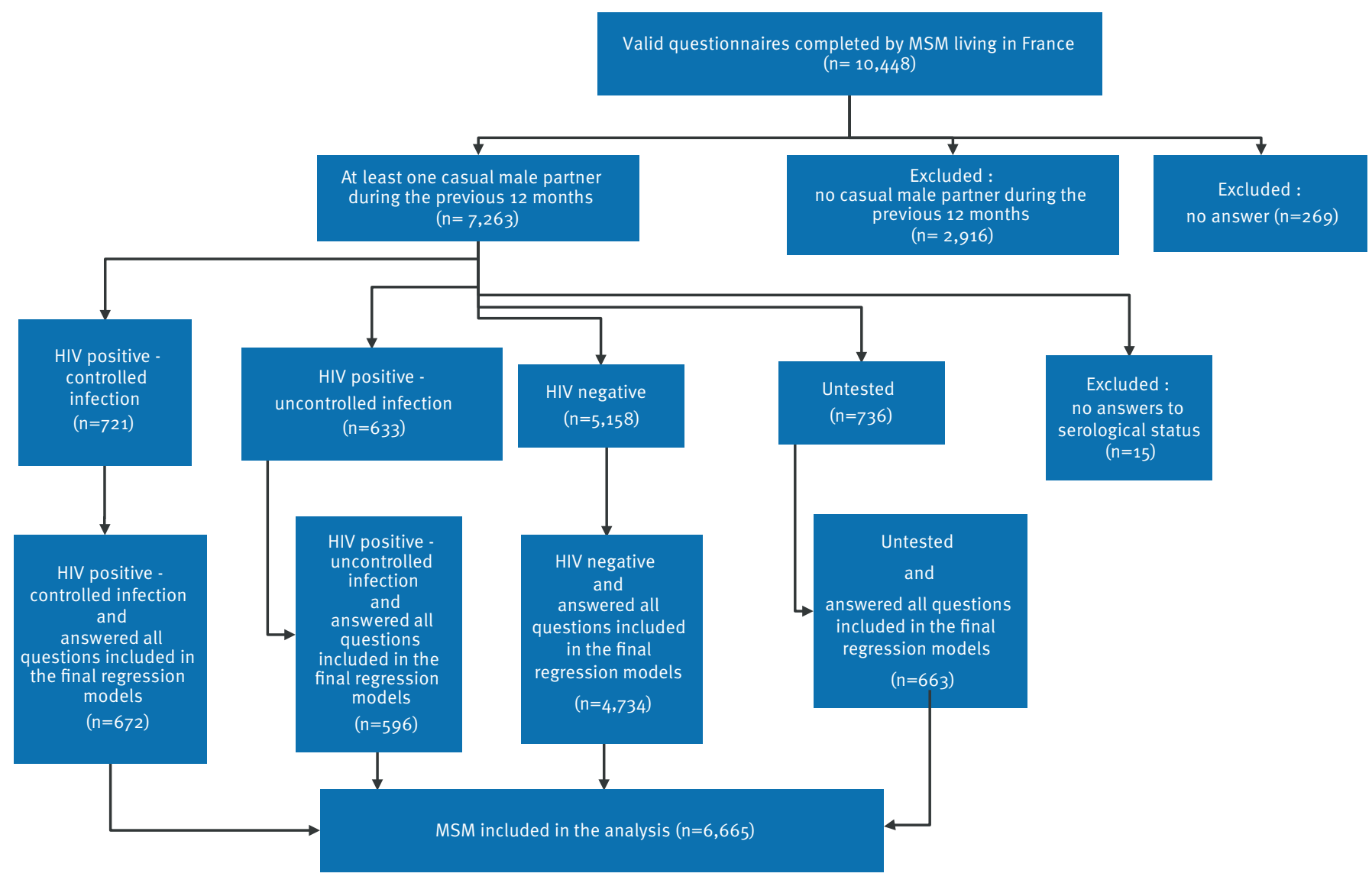

MSM: men who have sex with men.

HIV status. Second, we characterise the profiles of respondents with high-risk sexual practices to improve our understanding of the determinants of risk-taking.

\section{Methods}

The Presse Gays et Lesbiennes survey (Enquête Presse Gays et Lesbiennes, EPGL) is one of the tools used for behavioural surveillance of HIV and other sexually transmitted infections (STI) among MSM in France [14]. The survey is anonymous, cross-sectional, self-administered and voluntary. The most recent survey questionnaire was inserted in paper format in a monthly gay magazine in June 2011 and posted on the Internet between May and July 2011, accessible through a study-specific website. Participants were recruited through more than 60 information and dating websites for MSM. Web banners, personalised messages and recommendations via Facebook were used to invite MSM Internet users to participate online. There were no inclusion criteria, but the voluntary nature of this study led to the exclusion of some respondents from the analysis. The exclusion rate was higher on the Internet than in the press ( $9 \%$ v. $5 \%$ ). Of the 10,286 questionnaires completed by men from the Internet, 112 were excluded because respondents reported having had sex exclusively with women, three because respondents reported that they were younger than 14 years-old, and 779 because respondents reported they were not resident in France. Of the 1,110 questionnaires from the press, 54 from men not residing in France were excluded.

The questions asked in the paper and Internet questionnaires were identical. Data were collected on sociodemographic characteristics, social behaviours, sexual and preventive practices. Specifically, respondents were asked to provide, separately for each steady or casual partner in the previous 12 months, information about oral sex, insertive and receptive anal intercourse, condom use, number of UAl episodes, and knowledge of partners' serostatus.

Questions were also asked about HIV testing, both lifetime and during the previous 12 months, and selfreported HIV status at the time of the survey (HIVnegative, HIV-positive). The HIV status indicator is based on the lifetime HIV testing question and selfreported current HIV status. 
Definitions of four categories of sexual prevention behaviours, Presse Gays et Lesbiennes survey, France, 2011

\begin{tabular}{|c|c|}
\hline $\begin{array}{l}\text { Category of sexual } \\
\text { prevention behaviour }\end{array}$ & Definition \\
\hline No anal intercourse & $\begin{array}{l}\text { This category comprises respondents who did not report anal intercourse with casual partners in the previous } \\
12 \text { months but who may have had other types of sexual practices (mutual masturbation, oral sex, fisting, } \\
\text { etc.). }\end{array}$ \\
\hline Consistent condom use & $\begin{array}{l}\text { This category comprises respondents who had had anal intercourse with casual partners in the previous } 12 \\
\text { months and had systematically used condoms both insertive and receptive intercourse. }\end{array}$ \\
\hline Risk-reduction practices & $\begin{array}{l}\text { Exclusive serosorting } \\
\text { Respondents who reported they were HIV-positive or HIV-negative and had at least one episode of } \\
\text { unprotected anal intercourse only with casual partners of the same serostatus as themselves in the previous } \\
12 \text { months, were classified in this category. } \\
\text { Exclusive seropositioning } \\
\text { This category comprises respondents who reported they were HIV-positive or HIV-negative and had at least } \\
\text { one episode of UAl with casual partners of different or unknown serostatus from themselves in the previous } \\
12 \text { months, and had exclusively insertive anal intercourse for HIV-negative respondents and exclusively } \\
\text { receptive anal intercourse for HIV-positive respondents. } \\
\text { Serosorting and seropositioning } \\
\text { Respondents who declared they were HIV-positive or HIV-negative and had at least one episode of UAI with } \\
\text { casual partners in the previous } 12 \text { months, and who reported serosorting and seropositioning, were classified } \\
\text { in this category. }\end{array}$ \\
\hline $\begin{array}{l}\text { No discernible prevention } \\
\text { practice (NDPP) }\end{array}$ & $\begin{array}{l}\text { Respondents who had had UAI with casual partners in the previous } 12 \text { months without implementing any of } \\
\text { the risk reduction practices (serosorting, seropositioning), regardless of their HIV serostatus, were classified } \\
\text { in this category. }\end{array}$ \\
\hline
\end{tabular}

Seropositive MSM also answered questions about treatment (if any), viral load, and CD4 count over the past 12 months. They were then classified into two categories - with controlled or uncontrolled infection. In accordance with the Swiss statement recommendations [15], control was defined in relation to both HIV infection and other STIs (urogenital or rectal gonorrhoea, syphilis, hepatitis B, genital herpes, genital warts, chlamydia infection and lymphogranuloma venereum). Thus, regardless of whether they were on treatment, HIV-positive respondents who reported an undetectable viral load and a CD4 count greater than 500 cells/ $\mu \mathrm{L}$ in the previous 12 months and no other STI over the same period were considered to have controlled infection. All other HIV-positive respondents were classified with uncontrolled infection.

Reported sexual prevention behaviours with casual partners in the previous 12 months were categorised into four mutually exclusive categories (Table 1): no anal intercourse, consistent condom use, risk-reduction strategies, and no discernible prevention practice (NDPP). These sexual prevention behaviour categories were applied to each serostatus: HIV-positive respondents with controlled infection, HIV-positive respondents with uncontrolled infection, HIV-negative respondents and untested respondents.

\section{Statistical analyses}

All statistical analyses were stratified on HIV status. Logistic regressions were performed to investigate bivariate associations between NDPP and sociodemographic and behavioural factors. All factors significantly associated in bivariate analyses with NDPP in at least one HIV status stratum were considered candidate variables for the multivariable analyses. Correlation and multicollinearity between these candidate variables were examined before entering them in multivariable logistic regression models. Interactions were also evaluated. The Hosmer-Lemeshow test was used to evaluate the goodness-of-fit of the final four multivariable models. Statistical analyses were performed with Stata software version 12.0.

\section{Results}

Overall, 10,448 men living in France responded to the survey, principally over the Internet $(90 \% ; n=9,392)$. Our analysis was restricted to those who reported sexual intercourse with casual partners during the previous 12 months, self-reported their current HIV status and answered all the questions used in the multivariate analysis $(n=6,665)$ (Figure).

Their median age was 37 years (range: $15-87$ years), $72 \%(n=4,765)$ had a university degree and $32 \%$ $(n=2,127)$ lived in large urban areas (more than 500,000 inhabitants) (Table 2 ). In the previous 12 months, $49 \%$ $(n=3,239)$ had had a steady male partner, and $23 \%$ $(n=1,532)$ had regularly frequented sex venues. The median number of sexual partners was 10 (range: $1-100)$. Among all respondents, $14 \%(n=938)$ reported at least one STI in the previous 12 months, and among HIV-positive respondents, $31 \%(n=388)$. 


\section{TABLE 2}

Sociodemographic and behavioural characteristics of respondents who had a casual partner at least once in the previous 12 months, according to HIV serological status, Presse Gays et Lesbiennes survey, France, $2011(\mathrm{n}=6,665)$
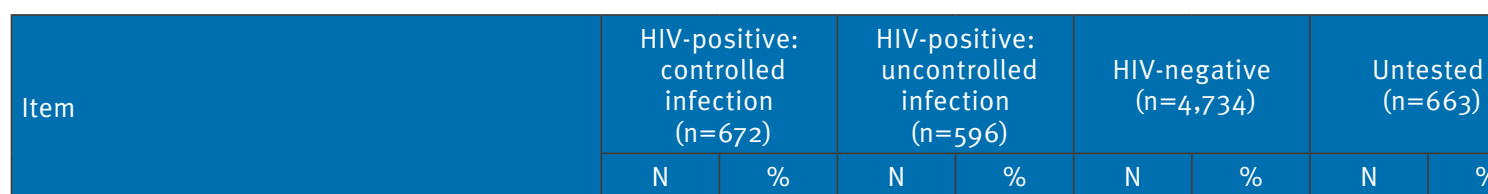

\section{Age (years)}

\begin{tabular}{|c|c|c|c|c|c|c|c|c|c|c|}
\hline$<30$ & 29 & $4 \cdot 3$ & 71 & 11.9 & 1,518 & 32.1 & 400 & 60.3 & 2,018 & 30.3 \\
\hline $30-44$ & 306 & $45 \cdot 5$ & 335 & 56.2 & 2,043 & 43.2 & 144 & 21.7 & 2,828 & 42.4 \\
\hline 45 or more & 337 & 50.1 & 190 & 31.9 & 1,173 & 24.8 & 119 & 17.9 & 1,819 & 27.3 \\
\hline \multicolumn{11}{|l|}{ Higher education } \\
\hline No & 227 & 33.8 & 175 & 29.4 & 1,226 & $25 \cdot 9$ & 272 & 41.0 & 1,900 & 28.5 \\
\hline Yes & 445 & 66.2 & 421 & 70.6 & 3,508 & 74.1 & 391 & 59.0 & 4,765 & 71.5 \\
\hline \multicolumn{11}{|l|}{ Activity status } \\
\hline Student & 7 & 1.0 & 13 & 2.2 & 634 & $13 \cdot 4$ & 244 & 36.8 & 898 & $13 \cdot 5$ \\
\hline Employee or self-employed & 540 & 80.4 & 477 & 80.0 & 3,531 & 74.6 & 350 & 52.8 & 4,898 & 73.5 \\
\hline Other (retired, unemployed) & 125 & 18.6 & 106 & 17.8 & 569 & 12.0 & 69 & 10.4 & 869 & 13.0 \\
\hline \multicolumn{11}{|l|}{ Urban area (inhabitants) } \\
\hline$<20,000$ & 151 & 22.5 & 114 & 19.1 & 1,302 & $27 \cdot 5$ & 244 & 36.8 & 1,811 & 27.2 \\
\hline 20,000 to 500,000 & 252 & 37.5 & 200 & 33.6 & 1,991 & 42.1 & 284 & 42.8 & 2,727 & 40.9 \\
\hline \multicolumn{11}{|c|}{ Frequented sex venues regularly during the previous 12 months } \\
\hline Yes & 241 & $35 \cdot 9$ & 243 & 40.8 & 947 & 20.0 & 101 & 15.2 & 1,532 & 23.0 \\
\hline No & 431 & 64.1 & 353 & 59.2 & 3,787 & 80.0 & 562 & 84.8 & 5,133 & 77.0 \\
\hline
\end{tabular}

Frequented dating websites regularly during the previous 12 months

\begin{tabular}{|c|c|c|c|c|c|c|c|c|c|c|}
\hline Yes & 446 & 66.4 & 479 & 80.4 & 2,914 & 61.6 & 431 & 65.0 & 4,270 & 64.1 \\
\hline No & 226 & 33.6 & 117 & 19.6 & 1,820 & 38.4 & 232 & 35.0 & 2,395 & 35.9 \\
\hline
\end{tabular}

Steady partner during the previous 12 months

\begin{tabular}{|c|c|c|c|c|c|c|c|c|c|c|}
\hline No & 352 & 52.4 & 322 & 54.0 & 2,308 & 48.8 & 444 & 67.0 & 3,426 & 51.4 \\
\hline Yes & 320 & 47.6 & 274 & 46.0 & 2,426 & 51.2 & 219 & 33.0 & 3,239 & 48.6 \\
\hline \multicolumn{11}{|c|}{ More than 10 male partners during the previous 12 months } \\
\hline No & 245 & 36.5 & 155 & 26.0 & 2,976 & 62.9 & 551 & 83.1 & 3,927 & 58.9 \\
\hline
\end{tabular}

Exposure to semen during oral sex during the previous 12 months (at least once)

\begin{tabular}{|c|c|c|c|c|c|c|c|c|c|c|}
\hline Yes & 503 & 74.9 & 485 & 81.4 & 2,605 & 55.0 & 356 & 53.7 & 3,949 & 59.2 \\
\hline No & 169 & 25.1 & 111 & 18.6 & 2,129 & 45.0 & 307 & 46.3 & 2,716 & 40.8 \\
\hline
\end{tabular}

Drug use during the previous 12 months (at least once)

\begin{tabular}{|c|c|c|c|c|c|c|c|c|c|c|}
\hline Yes & 522 & 77.7 & 517 & 86.7 & 2,613 & 55.2 & 273 & 41.2 & 3,925 & 58.9 \\
\hline No & 150 & 22.3 & 79 & $13 \cdot 3$ & 2,121 & 44.8 & 390 & 58.8 & 2,740 & 41.1 \\
\hline \multicolumn{11}{|c|}{ HIV test during the previous 12 months } \\
\hline No & 391 & $64 \cdot 5$ & 331 & 59.9 & 1,476 & 31.2 & n.a. & n.a. & 2,198 & 37.3 \\
\hline \multicolumn{11}{|c|}{ HIV diagnosis (year) } \\
\hline Before 1997 & 282 & 42.0 & 135 & 22.7 & n.a. & n.a. & n.a. & n.a. & 417 & 32.9 \\
\hline $1997-2000$ & 90 & 13.4 & 70 & 11.7 & n.a. & n.a. & n.a. & n.a. & 160 & 12.6 \\
\hline After 2000 & 300 & 44.6 & 391 & 65.6 & n.a. & n.a. & n.a. & n.a. & 691 & $54 \cdot 5$ \\
\hline \multicolumn{11}{|c|}{ At least one STI during the previous 12 months } \\
\hline Yes & 0 & 0.0 & 388 & 65.2 & 520 & 11.0 & 30 & 4.6 & 938 & 14.1 \\
\hline No & 672 & 100.0 & 207 & 34.8 & 4,206 & 89.0 & 629 & 95.4 & 5,714 & 85.9 \\
\hline
\end{tabular}

n.a.: not applicable; STI: sexually transmitted infection. 
Prevalence of sexual preventive behaviour with casual partners during the previous 12 months according to respondent's HIV status, Presse Gays et Lesbiennes survey, France, 2011, $(n=6,665)$

\begin{tabular}{|c|c|c|c|c|c|c|c|c|c|c|c|}
\hline & \multicolumn{2}{|c|}{$\begin{array}{l}\text { HIV-positive: } \\
\text { controlled } \\
\text { infection }^{\mathrm{a}} \\
(\mathrm{n}=672)\end{array}$} & \multicolumn{2}{|c|}{$\begin{array}{l}\text { HIV-positive: } \\
\text { uncontrolled } \\
\text { infection }^{b} \\
\quad(n=596)\end{array}$} & \multicolumn{2}{|c|}{$\begin{array}{l}\text { HIV-negative } \\
\qquad(\mathrm{n}=4,734)\end{array}$} & \multicolumn{2}{|c|}{$\begin{array}{l}\text { Untested } \\
(\mathrm{n}=663)\end{array}$} & \multicolumn{2}{|c|}{$\begin{array}{c}\text { Total } \\
(n=6,665)\end{array}$} & \multirow[t]{2}{*}{$p$ values } \\
\hline & $\mathrm{N}$ & $\%$ & $\mathrm{~N}$ & $\%$ & $\mathrm{~N}$ & $\%$ & $\mathrm{~N}$ & $\%$ & $\mathrm{~N}$ & $\%$ & \\
\hline No anal intercourse & 20 & 3.0 & 13 & 2.2 & 393 & 8.3 & 107 & 16.2 & 533 & 8.0 & $p<0.001$ \\
\hline $\begin{array}{l}\text { Consistent condom use during anal } \\
\text { intercourse }\end{array}$ & 148 & 22.0 & 79 & $13 \cdot 3$ & 2,603 & $55 \cdot 0$ & 329 & 49.6 & 3,159 & $47 \cdot 4$ & $p<0.001$ \\
\hline \multicolumn{12}{|l|}{ Unprotected anal intercourse } \\
\hline \multicolumn{12}{|l|}{ Risk reduction practices } \\
\hline - Exclusive serosorting & 104 & $15 \cdot 5$ & 86 & $14 \cdot 4$ & 389 & 8.2 & n.a. & n.a. & 579 & 8.7 & $p<0.001$ \\
\hline - Exclusive seropositioning & 82 & 12.2 & 80 & 13.4 & 260 & $5 \cdot 5$ & n.a. & n.a. & 422 & 6.3 & $p<0.001$ \\
\hline - Serosorting and seropositioning & 14 & 2.1 & 11 & 1.8 & 105 & 2.2 & n.a. & n.a. & 130 & 2.0 & $p=0.831$ \\
\hline No discernible prevention practice & 304 & 45.2 & 327 & $54 \cdot 9$ & 984 & 20.8 & 227 & 34.2 & 1,842 & 27.6 & $p<0.001$ \\
\hline Total & 672 & 100.0 & 596 & 100.0 & 4,734 & 100.0 & 663 & 100.0 & 6,665 & 100.0 & \\
\hline
\end{tabular}

n.a.: not applicable.

Positive controlled infection: HIV-positive respondents reported that during the previous 12 months they had either antiretroviral treatment, and an undetectable viral load, and no other STI or no treatment but an undetectable viral load and a CD4 Count greater than 500 cells/ $\mu$ L, and no other STI.

b Positive uncontrolled infection: HIV-positive respondents who did not meet the criteria for controlled infection.

Prevalence of sexual preventive behaviours with casual male partners

The proportion of respondents practicing no anal intercourse with their casual partners in the previous 12 months was low: ranging from $2 \%(n=13)$ among HIVpositive respondents with uncontrolled infection to $16 \%(n=107)$ among untested respondents (Table 3 ). Consistent condom use during anal intercourse was more frequent among HIV-negative respondents ( $55 \%$; $n=2,603)$ and untested $(50 \% ; n=329)$ than HIV-positive respondents (Table 3 ). HIV-positive respondents with uncontrolled infection reported less consistent condom use than those with controlled infection $(13 \%(n=79)$ vs $22 \%(n=148), p<0.001)$. Risk-reduction practices were reported more often by HIV-positive respondents (30\%; $n=377$ ), regardless of infection control status, than by HIV-negative respondents ( $16 \% ; n=754)$. Exclusive serosorting was practiced more than exclusive seropositioning, regardless of HIV status. No difference was found between HIV-positive respondents with controlled and uncontrolled infection for risk-reduction practices (Table 3). NDPP was reported more frequently by HIV-positive respondents with uncontrolled $(55 \%$; $n=327)$ and controlled infection ( $45 \% ; n=304)$, than by untested $(34 \% ; n=227)$ or HIV-negative respondents $(21 \% ; n=984)$ (Table 3$)$.

\section{Factors associated with no discernible} prevention practice

Univariate analysis (Table 4) showed associations between NDPP and a set of common variables, regardless of serostatus. These variables included age younger than 30 years, no university degree, and each of the following within the previous 12 months: regular frequentation of sex venues and dating websites, a high number of sexual partners, drug use, and exposure to sperm during oral sex. For HIV-positive respondents with controlled or uncontrolled infection, they also included HIV diagnosis after 2000. Multivariate analyses (Table 4) highlighted significant differences in the profiles of NDPP-classified respondents according to their serostatus.

For HIV-positive respondents with controlled infection, NDPP was associated with age younger than 30 years (adjusted odds ratio $(\mathrm{aOR})=2.9$, (95\% confidence interval (Cl): 1.1-8.0)), HIV diagnosis after $2000(a O R=2.0$, (95\% Cl: 1.3-3.0)), and each of the following within the previous 12 months: regular frequentation sex venues $(\mathrm{aOR}=1.7,(95 \% \mathrm{Cl}: 1.2-2.4))$, more than 10 partners $(\mathrm{aOR}=2.3,(95 \% \mathrm{Cl}: 1.6-3.4))$, and exposure to sperm during oral sex $(\mathrm{aOR}=1.9,(95 \% \mathrm{Cl}: 1.3-3.0))$ (Table 4).

For HIV-positive respondents with uncontrolled infection, NDPP was associated with unemployment $(\mathrm{aOR}=1.8 ;(95 \% \mathrm{Cl}: 1.1-3.0))$, residence in a mediumsized urban area $(\mathrm{aOR}=1.5$; $(95 \% \mathrm{Cl}: 1.0-2.3))$, post2000 diagnosis $(\mathrm{aOR}=1.7 ;(95 \% \mathrm{Cl}: 1.1-2.7))$, and each of the following in the previous 12 months: regular frequentation sex venues $(\mathrm{aOR}=1.5 ;(95 \% \mathrm{Cl}$ : 1.0-2.1)), more than 10 partners $(\mathrm{aOR}=2.6 ;(95 \% \mathrm{Cl}: 1.7-4.0))$ and exposure to sperm during oral sex $(a O R=2.6$; (95\% Cl: 1.6-4.3)) (Table 4).

For HIV-negative respondents, NDPP was associated with age younger than 45 years ( 330 years: $\mathrm{aOR}=1.4 ;(95 \% \mathrm{Cl}: 1.2-1.8) ; 30-44$ years: $\mathrm{aOR}=1.3$; $(95 \% \mathrm{Cl}: 1.0-1.5))$, no university degree $(\mathrm{aOR}=1.5 ;(95 \%$ 


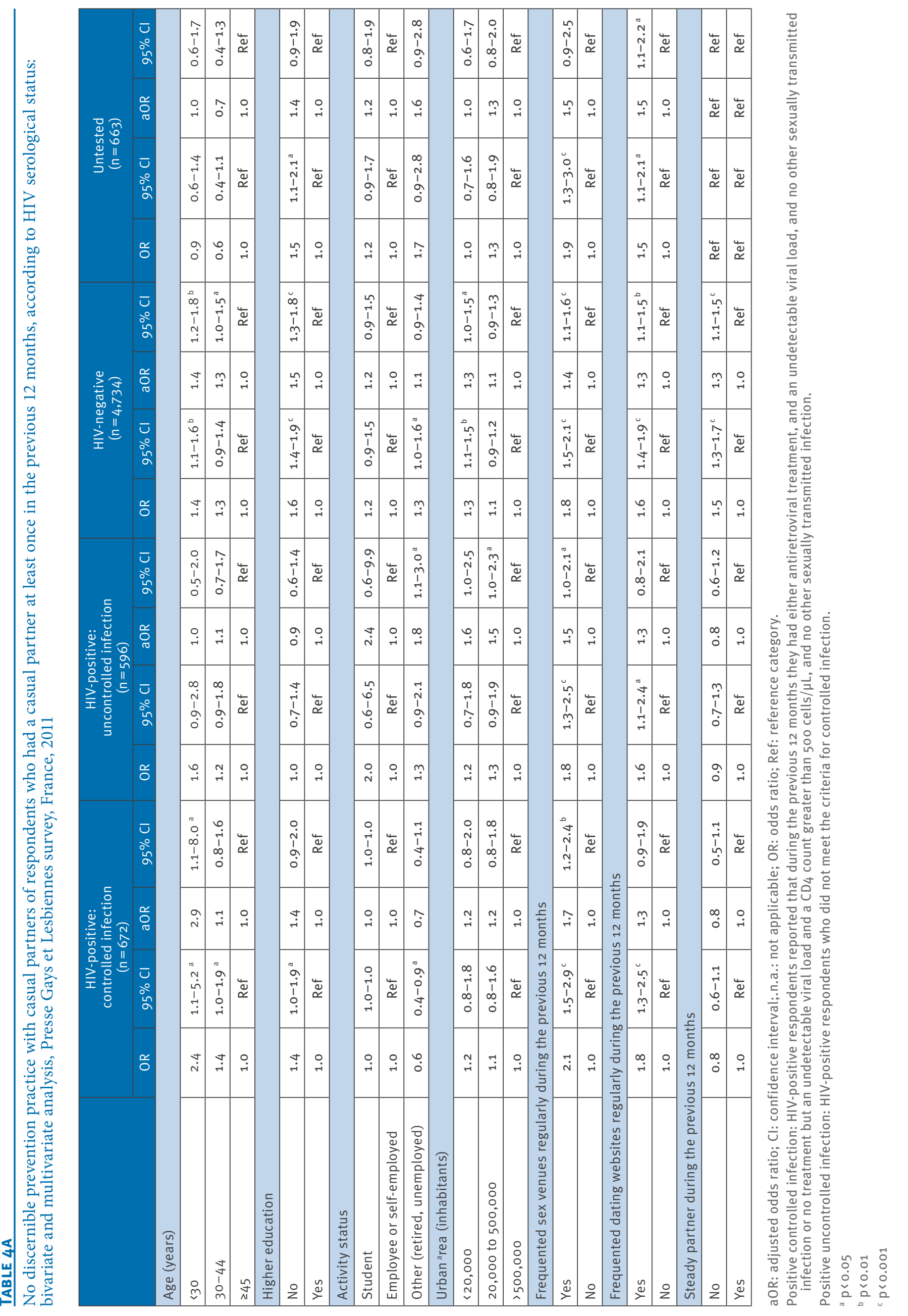




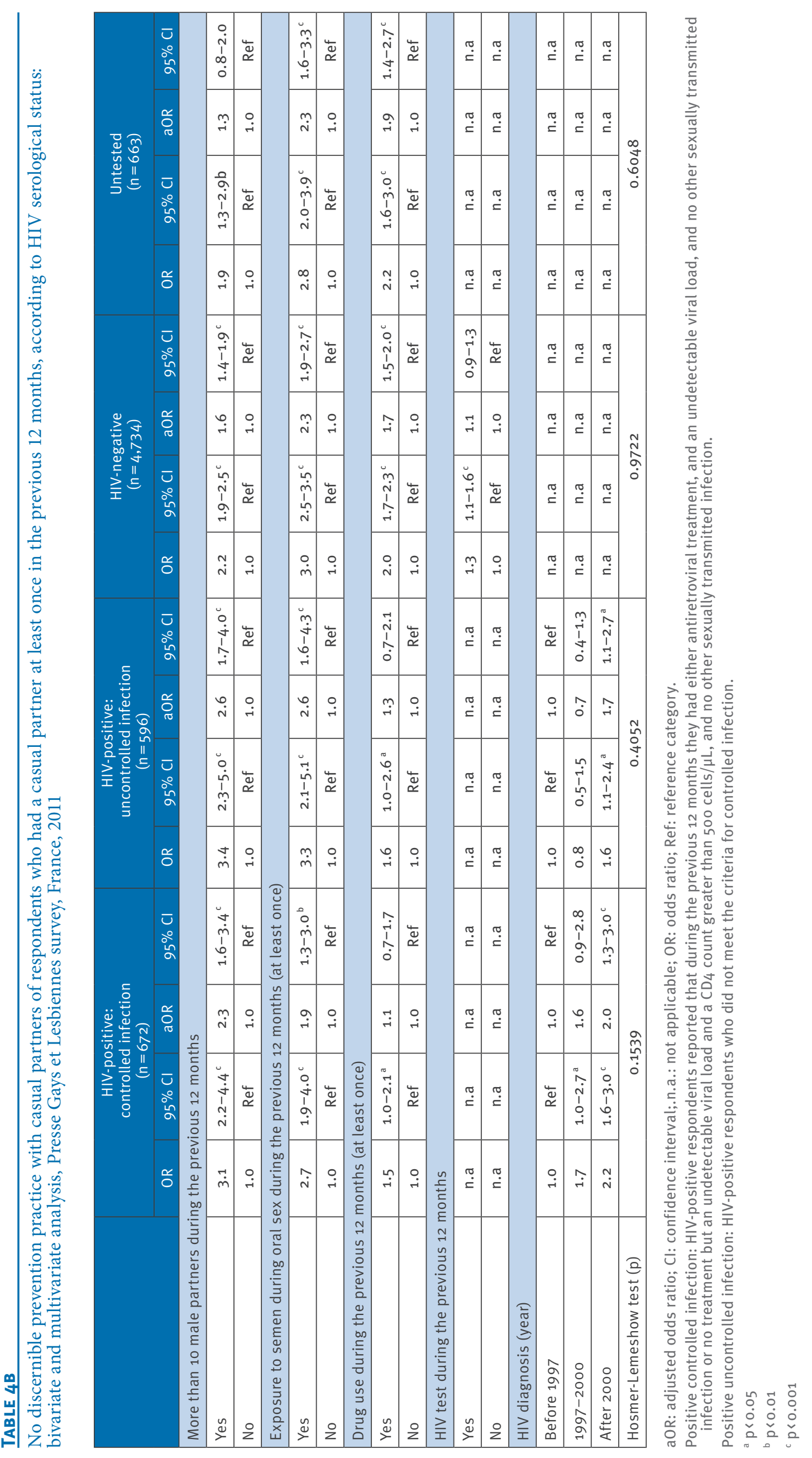


$\mathrm{Cl}: 1.3-1.8)$ ), residence in an urban area of fewer than 20,000 inhabitants $(\mathrm{aOR}=1.3 ;(95 \% \mathrm{Cl}: 1.0-1.5)$ ), and each of the following during the previous 12 months: regular frequentation sex venues $(\mathrm{aOR}=1.4 ; \quad 95 \%$ $\mathrm{Cl}$ : 1.1-1.6)), regular frequentation dating websites $(\mathrm{aOR}=1.3$; $(95 \% \mathrm{Cl}: 1.1-1.5))$, no steady sexual partner $(\mathrm{aOR}=1.3 ;(95 \% \mathrm{Cl}: 1.1-1.5))$, more than 10 partners $(\mathrm{aOR}=1.6$; $(95 \% \mathrm{Cl}: 1.4-1.9))$, exposure to sperm during oral sex $(\mathrm{aOR}=2.3 ;(95 \% \mathrm{Cl}: 1.9-2.7))$ and drug use $(\mathrm{aOR}=1.7 ;(95 \% \mathrm{Cl}: 1.5-2.0))($ Table 4$)$.

For untested respondents, NDPP was associated with all of the following activities in the previous 12 months: regular frequenting dating websites $(\mathrm{aOR}=1.5 ;(95 \% \mathrm{Cl}$ : 1.1-2.2)), exposure to sperm during oral $\operatorname{sex}(\mathrm{aOR}=2.3$; 95\% Cl: 1.6-3.3)) and drug use (aOR=1.9; (95\% Cl: $1.4-$ 2.7)) (Table 4).

\section{Discussion}

\section{Description of survey}

The Presses Gays et Lesbiennes survey is one of the very few surveys in France that describe the sexual behaviours of MSM in detail, based on a large sample of volunteers. Its use of the Internet as its principal mode of recruitment brought forth a wide variety of respondents, in terms of age, place of residence and sociodemographic profile. Because most respondents had had at least one casual partner in the previous 12 months, these data gave us a good understanding of prevention practices used by MSM in such relationships.

\section{Major results}

Because our categorisation of sexual prevention behaviours captures the diversity of preventive practices among MSM, we were able to obtain a detailed description of them. Thirty years after the HIV epidemic started, condom use during anal intercourse was not widespread, regardless of HIV status [1]. More detailed information about the determinants of consistent condom use would be interesting, but it seemed to us most useful to describe specific profiles of MSM engaged in high risk-taking in order to implement target prevention programs according to HIV status. Riskreduction strategies were used to a limited degree by HIV-positive respondents, with no difference according to disease control status, and to a lesser degree by their seronegative counterparts. Nevertheless, a large proportion of respondents had NDPP, a finding consistent with other European studies which used unprotected anal intercourse as the principal indicator of risk-taking $[7,16,17]$. The factors associated with this lack of protection reflect a number of common characteristics generally associated with risk-taking. These include frequenting Internet meeting sites, using drugs, and exposure to sperm during oral sex [17-19]. In particular, HIV-positive respondents with NDPP most often belonged to the post-AIDS generation and had an adventure-oriented sexuality [20]. HIV-negative respondents with NDPP were characterised by a low education level.
Importance of HIV testing

In this context, HIV testing and knowledge of status are major issues. More than one third of untested respondents and one in five of the HIV-negative respondents engaged in high-risk practices that put them and their sexual partners at risk for HIV infection and other STIs. MSM unaware of their status who engage in these behaviours contribute to driving the hidden epidemic, estimated in France to be more than 9,000 MSM [11]. A seroprevalence study in Paris showed that $20 \%$ of undiagnosed HIV-positive respondents reported that they either had never previously been tested or were HIV-negative, but had the same sexual risk behaviours as HIV-positive men aware of their status [17]. It is crucial that untested MSM be encouraged to go for HIV testing and receive counselling on risk-reduction strategies. Accordingly, structural and psychological barriers to testing must be reduced, especially denial about practicing at-risk behaviours and fear of positive HIV test results [21]. It is also essential for HIVnegative respondents to regularly update their HIV status. However, our results did not show any association between NDPP and testing within the previous 12 months. This suggests that these HIV-negative men had not actually recognised that they engaged in riskbehaviours and wrongly believed themselves to be HIV-negative. Encouraging MSM to test for HIV as frequently as possible to confirm their negative status is vital [21].

\section{Risk-reduction practices and their limitations} MSM have taken up serosorting or seropositioning as alternative risk-reduction practices to condom use [7]. Studies have previous associated these practices with positive HIV-status [22,23]. In our study, a substantial proportion of HIV-positive respondents used them, regardless of whether their infection was controlled or not. HIV-negative respondents also engaged in these practices, although at a rate lower than in other studies [22]. Nevertheless, the efficacy of both serosorting and seropositioning has been questioned. Their levels of scientific validation differ, and randomised trials have failed to demonstrate their efficacy. Some studies have shown they have a positive effect on the epidemic's dynamics [6], while others have not [24]. Unlike condom use, these practices do not protect against STIs and are only effective for HIV transmission if both partners have up-to-date knowledge of their serostatus [25]. Moreover, they must discuss the issue, something that cannot always be taken for granted, given the nature of meeting places and the problems of discrimination against seropositive MSM.

\section{Vulnerability of HIV-negative men who have sex with men}

HIV-negative respondents displaying NDPP appeared to be more socially vulnerable than other subgroups in our study. Although they were part of the gay community, they had profiles associated with high-risk sexual behaviours: young, with low education levels, and living in non-urban areas. The increase in newly 
diagnosed HIV cases among MSM under 30 years old in Europe [2,26], and in France more specifically [3], confirms our findings. Interventions targeting younger MSM are urgently needed to prevent a resurgence of the epidemic.

Moreover, as in our study, a low educational level was found to be associated with risk-taking behaviours in the EMIS network [16] and with an increased risk of HIV seroconversion in European studies [26,27]. These findings must be integrated into prevention campaigns to tailor prevention messages as well as possible to ensure the widest possible participation by this specific population.

\section{Heterogeneity of practices among HIV-positive MSM}

Our findings underline the heterogeneity of preventive behaviours among HIV-positive MSM and the need to take this diversity into account to improve therapeutic care. In accordance with the Swiss statement's recommendations [15], in view of the different transmission issues, we categorised HIV-positive MSM according to whether their infection was controlled or uncontrolled and analysed them separately. Randomised trials have shown that treatment, by controlling viral load, reduces the risk of transmission in heterosexual couples [8] and in steady MSM couples [28]. No such result has been observed in MSM for casual relationships $[9,29]$.

Interestingly, in our study, HIV-positive respondents with controlled infection were less likely to show NDPP than those whose infection was uncontrolled. This finding might be due in part to how we constructed the infection control status categories, by considering STI infections as well as viral load over the last 12 months. But this finding is also consistent with a seroprevalence study which showed that HIV-positive MSM in Paris with a low viral load reported a lower proportion of UAl episodes with casual partners of unknown or different HIV status than their counterparts with high viral loads [30].

The association of diagnosis after 2000 with NDPP, regardless of infection control status, demonstrates the generational impact and the effect of treatment on sexual behaviours [31]. A high proportion of the HIVpositive respondents in this study were diagnosed after 2000, at a time when barebacking was emerging and engendering fierce debates and long-term divisions between MSM in France [32]. Some of these men also started their sexual life after the arrival of antiretroviral treatment (ART). Furthermore, the hypothesis of behavioural disinhibition linked to treatment seems be true for this sub-population [33]. These results highlight the urgent need to implement targeted information campaigns for HIV-positive MSM and thus to remind individuals and groups about the importance of treatment adherence, about STI care and about the place of condoms in sexual practices with casual partners.

\section{Study limitations}

Our study also has some limitations that must be considered in interpreting our results. First, the methodological limitations must be underlined. As is often the case for surveys related to MSM [14], our study is based on a non-random sample with participant self-selection through the Internet and gay press. Furthermore, the absence of both a sample frame and controls during the inclusion process means that our results cannot be extrapolated to the entire MSM population [1]. We did, however, use websites as varied as possible to invite MSM to participate. MSM recruited through the press have a more established sexual identity and sex life as well as higher educational and economic levels [34]. Those recruited through the Internet are younger and less urban [35]. Furthermore, the serological data based on self-reporting probably underestimated the real proportion of HIV-positive MSM as some respondents were probably unaware that they were HIVpositive. This point has previously been highlighted in studies on seroprevalence in MSM $[17,36]$.

Second, the categorisation we used also has limitations. It was constructed retrospectively, based on the answers to questions about sexual behaviours and selfreported health status. It was not based on questions about a deliberate choice to use serosorting or seropositioning instead of condoms [37,38]. Nevertheless, a comparison of the risk-reduction practices and strategies matched the responses well: $90 \%$ of the respondents classified as engaging in serosorting declared they did so to avoid contamination by or transmission of HIV. Another limitation of the categorisation used is that making the risk-reduction categories mutually exclusive is simplistic and inaccurate. It does not take into account the protean reality of different sexual behaviours over time (in this case 12 months) [37] and is the result of a theoretical compromise.

\section{Conclusions}

The study captured the diversity of preventive practices among MSM. Our findings highlight the ongoing nature of the normalisation of HIV in this post-AIDS era [39], when HIV has lost the central meaning it had in the lives of gay men in the 1980 s and 1990 . Furthermore, the ever-decreasing use of condoms means that HIV testing and treatment are not sufficient to invert the epidemic's trend. Combination prevention is legitimate in the current context where HIV incidence remains very high worldwide. Accordingly, promoting condom use, encouraging regular HIV testing, offering treatment - be it post-exposure (PeP) or pre-exposure (PreP) - to HIV-negative MSM at high risk of exposure, prompt treatment of HIV-positive MSM and, finally, follow-up for STIs are all interventions that belong in prevention programmes for MSM within a global health approach. 
Funding

The Presse Gays et Lesbiennes survey 2011 was funded by the French National Agency for Research on AIDS and Viral Hepatitis (ANRS).

\section{Acknowledgements}

The authors thank the Internet sites and monthly magazines who published the survey questionnaire, the teams who developed the dedicated Internet site, the French National Agency for Research on AIDS and Viral Hepatitis (ANRS) for its scientific support, and the ANRS members on the Presse Gays et Lesbiennes survey 2011 scientific committee. Alice Bouyssou for statistical support, Jude Sweeney for his translation and editing of the English manuscript, Jo Ann Cahn for her revision of the English manuscript and all the men who took the time to take part in the survey.

\section{Conflicts of interest}

None declared.

\section{Authors' contributions}

AV was the principal investigator of the Presse Gays et Lesbiennes survey 2011, carried out the statistical analysis, and conceived and wrote the paper. LS carried out the statistical analysis, commented on the first draft and approved the final version. CSommen carried out the statistical analysis, commented on the first draft and approved the final version, PB carried out the statistical analysis, commented on the first draft of the paper and approved the final version, NB commented on the first draft of the paper and approved the final version, CSemaille commented on the first draft of the paper and approved the final version.

\section{References}

1. Beyrer C, Baral SD, van Griensven F, Goodreau SM, Chariyalertsak S, Wirtz AL, et al. Global epidemiology of HIV infection in men who have sex with men. Lancet. 2012;380(9839):367-77. http://dx.doi.org/10.1016/S01406736(12)60821-6 PMID:22819660

2. Pharris A, Spiteri G, Noori T, Amato-Gauci AJ. Ten years after Dublin: principal trends in HIV surveillance in the EU/EEA, 2004 to 2013. Euro Surveill. 2014;19(47):20968. http://dx.doi. org/10.2807/1560-7917.ES2014.19.47.20968 PMID:25443034

3. Cazein F, Pinget R, Lot F, Pillonel J, Le Strat Y, Sommel C, et al. Découvertes de séropositivité VIH et SIDA - France, 20032011 [New HIV and AIDS diagnoses - France, 2003-2011]. Bull Epidémiol Hebd. 2013;28-29:333-40. French. Available from: http://www.invs.sante.fr/beh/2013/28-29/pdf/2013_28-29_2. pdf

4. Le Vu S, Le Strat Y, Barin F, Pillonel J, Cazein F, Bousquet V, et al. Population-based HIV-1 incidence in France, 2003-08: a modelling analysis. Lancet Infect Dis. 2010;10(10):682-7. http:// dx.doi.org/10.1016/S1473-3099(10)70167-5 PMID:20832367

5. Elford J. Changing patterns of sexual behaviour in the era of highly active antiretroviral therapy. Curr Opin Infect Dis. 2006;19(1):26-32. http://dx.doi.org/10.1097/01. qco.0000199018.50451.e1 PMID:16374214

6. Cassels S, Katz DA. Seroadaptation among men who have sex with men: emerging research themes. Curr HIV/AIDS Rep. 2013;10(4):305-13. http://dx.doi.org/10.1007/s11904-013-01882 PMID:24234489

7. Hart GJ, Elford J. Sexual risk behaviour of men who have sex with men: emerging patterns and new challenges. Curr Opin Infect Dis. 2010;23(1):39-44. http://dx.doi.org/10.1097/ QC0.obo13e328334feb1 PMID:19949328

8. Cohen MS, Chen YQ, McCauley M, Gamble T, Hosseinipour MC, Kumarasamy N, et al.; HPTN 052 Study Team. Prevention of HIV-1 infection with early antiretroviral therapy. N Engl
J Med. 2011;365(6):493-505. http://dx.doi.org/10.1056/ NEJMoa1105243 PMID:21767103

9. Cambiano V, O'Connor J, Phillips AN, Rodger A, Lodwick $\mathrm{R}$, Pharris A, et al. Antiretroviral therapy for prevention of HIV transmission: implications for Europe. Euro Surveill. 2013;18(48):20647. http://dx.doi.org/10.2807/1560-7917. ES2013.18.48.20647 PMID:24308982

10. Centers for Disease Control and Prevention (CDC). HIV testing and risk behaviors among gay, bisexual, and other men who have sex with men - United States. MMWR Morb Mortal Wkly Rep. 2013;62(47):958-62. PMID:24280915

11. Supervie V, Ndawinz JD, Lodi S, Costagliola D. The undiagnosed HIV epidemic in France and its implications for HIV screening strategies. AIDS. 2014;28(12):1797-804. http:// dx.doi.org/10.1097/QAD.0000000000000270 PMID:24681416

12. Grant RM, Lama JR, Anderson PL, McMahan V, Liu AY, Vargas L, et al.; iPrEx Study Team. Preexposure chemoprophylaxis for HIV prevention in men who have sex with men. N Engl J Med. 2010;363(27):2587-99. http://dx.doi.org/10.1056/ NEJMoa1011205 PMID:21091279

13. Coates TJ, Richter L, Caceres C. Behavioural strategies to reduce HIV transmission: how to make them work better. Lancet. 2008;372(9639):669-84. http://dx.doi.org/10.1016/ S0140-6736(08)60886-7 PMID:18687459

14. Elford J, Jeannin A, Spencer B, Gervasoni JP, van de Laar MJ, Dubois-Arber F; HIV and STI Behavioural Surveillance Mapping Group. HIV and STI behavioural surveillance among men who have sex with men in Europe. Euro Surveill. 2009;14(47). PMID:19941807

15. Vernazza $P$, Hirschel $B$, Bernasconi E, Flepp $M$. Les personnes séropositives ne souffrant d'aucunes autre MST et suivant un traitement antirétroviral efficace ne transmetent pas le VIH par voie sexuelle. [HIV-positive people suffering from no other STD and adhering to effective antiretroviral therapy do not transmit HIV through sex]. Bulletin des Médecins Suisses. 2008;89:1659. French. Available from: http://www.bullmed.ch/docs/saez/ archiv/fr/2008/2008-05/2008-05-089.pdf

16. European Centre for Disease Prevention and Control (ECDC). EMIS 2010: The European Men-Who-Have-Sex-With-Men Internet Survey. Findings from 38 countries. Stockholm: ECDC; 2013. Available from: http://ecdc.europa.eu/en/publications/ Publications/EMIS-2010-european-men-who-have-sex-withmen-survey.pdf

17. Velter A, Barin F, Bouyssou A, Guinard J, Leon L, Le VS, et al. HIV Prevalence and Sexual Risk Behaviors Associated with Awareness of HIV Status Among Men Who Have Sex with Men in Paris, France. AIDS Behav. 2013;17(4):1266-78.

18. Leobon A, Velter A, Engler K, Drouin MC, Otis J. A relative profile of HIV-negative users of French websites for men seeking men and predictors of their regular risk taking: a comparison with HIV-positive users. AIDS Care. 2011;23(1):2534. http://dx.doi.org/10.1080/09540121.2010.498866 PMID:21218274

19. Meyer L, Seng R, Allègre T, Timsit J, Talamali A, Reynes J, et al. Increasing frequency of self-reported orogenital HIV-1 transmission among men having sex with men: The ANRS PRIMO Cohort. J Acquir Immune Defic Syndr. 2013;63(5):e1646. http://dx.doi.org/10.1097/QAl.obo13e318294bcec PMID:24135781

20. Kippax S, Campbell D, Van de Ven P, Crawford J, Prestage G, Knox S, et al. Cultures of sexual adventurism as markers of HIV seroconversion: a case control study in a cohort of Sydney gay men. AIDS Care. 1998;10(6):677-88. http://dx.doi. org/10.1080/09540129848307 PMID:9924523

21. Knussen C, Flowers P, McDaid LM. Factors associated with recency of HIV testing amongst men residing in Scotland who have sex with men. AIDS Care. 2014;26(3):297-303. http:// dx.doi.org/10.1080/09540121.2013.824543 PMID:23947757

22. Dubois-Arber F, Jeannin A, Lociciro S, Balthasar H. Risk reduction practices in men who have sex with men in Switzerland: serosorting, strategic positioning, and withdrawal before ejaculation. Arch Sex Behav. 2012;41(5):1263-72. http:// dx.doi.org/10.1007/S10508-011-9868-4 PMID:22083656

23. Jin F, Crawford J, Prestage GP, Zablotska I, Imrie J, Kippax SC, et al. Unprotected anal intercourse, risk reduction behaviours, and subsequent HIV infection in a cohort of homosexual men. AIDS. 2009;23(2):243-52. http://dx.doi.org/10.1097/ QAD.ob013e32831fb51a PMID:19098494

24. Heymer KJ, Wilson DP. Available evidence does not support serosorting as an HIV risk reduction strategy. AIDS. 2010;24(6):935-6, author reply 936-8. http://dx.doi. org/10.1097/QAD.ob013e328337b029 PMID:20234196

25. van den Boom W, Konings R, Davidovich U, Sandfort T, Prins $M$, Stolte IG. Is serosorting effective in reducing the risk of HIV infection among men who have sex with men with casual sex partners? J Acquir Immune Defic Syndr. 2014;65(3):375-9. 
http://dx.doi.org/10.1097/QAI.0000000000000051

PMID:24189150

26. Giuliani M, Vescio MF, Latini A, Palamara G, Pimpinelli F, Dona $M G$, et al. Continuous increase in HIV-1 incidence after the year 2000 among men who have sex with men in Rome: insights from a 25-year retrospective cohort study. Euro Surveill. 2014;19(47):20969. http://dx.doi.org/10.2807/1560-7917. ES2014.19.47.20969 PMID:25443035

27. Jansen IA, Geskus RB, Davidovich U, Jurriaans S, Coutinho RA, Prins $M$, et al. Ongoing HIV-1 transmission among men who have sex with men in Amsterdam: a 25-year prospective cohort study. AIDS. 2011;25(4):493-501. http://dx.doi.org/10.1097/ QAD.obo13e328342fbe9 PMID:21192230

28. Rodger A. HIV transmission risk trough condomless sex if HIV+ partner on suppressive ART: PARTNER study. 21st Conference on Retroviruses and Opportunistic Infections. [cited 2014].

29. Muessig KE, Smith MK, Powers KA, Lo YR, Burns DN, Grulich $\mathrm{AE}$, et al. Does ART prevent HIV transmission among MSM? AIDS. 2012;26(18):2267-73. http://dx.doi.org/10.1097/ QAD.ob013e328355713d PMID:22569019

30. Semaille C, Barin F, Bouyssou A, Peytavin G, Guinard J, Le Vu $S$, et al. High viral loads among HIV-positive MSM attending gay venues: implications for HIV transmission. J Acquir Immune Defic Syndr. 2013;63(3):e122-4. http://dx.doi.org/10.1097/ QAl.ob013e31829002ae PMID:23760098

31. Seng R, Rolland M, Beck-Wirth G, Souala F, Deveau C, Delfraissy JF, et al. Trends in unsafe sex and influence of viral load among patients followed since primary HIV infection, 2000-2009. AIDS. 2011;25(7):977-88. http://dx.doi. org/10.1097/QAD.ob013e328345ef12 PMID:21358375

32. Le Tallec JY. Le bareback: affirmation identitaire et transgression. [Bareback: identity affirmation and transgression]. In: Broqua C, Lert F, Souteyrand Y, editors. Homosexualités au temps du sida. Tensions sociales et identitaires. [Homosexualities in the time of AIDS. Social and identity tensions]. Paris: ANRS; 2014. p. 221-44. French.

33. Wilson DP, Law MG, Grulich AE, Cooper DA, Kaldor JM. Relation between HIV viral load and infectiousness: a model-based analysis. Lancet. 2008;372(9635):314-20. http://dx.doi. org/10.1016/S0140-6736(08)61115-o PMID:18657710

34. Sandfort TGM. Sampling male homosexuality. In J. Bancrofs, editor, Researching sexual behavior: methodological issues. Bloomington: Indiana University Press; 1997. p. 261-275.

35. Ross MW, Tikkanen R, Månsson SA. Differences between Internet samples and conventional samples of men who have sex with men: implications for research and HIV interventions. Soc Sci Med. 2000;51(5):749-58. http://dx.doi.org/10.1016/ So277-9536(99)00493-1 PMID:10975234

36. Williamson LM, Dodds JP, Mercey DE, Hart GJ, Johnson AM. Sexual risk behaviour and knowledge of HIV status among community samples of gay men in the UK. AIDS. 2008;22(9):1063-70. http://dx.doi.org/10.1097/ QAD.obo13e3282f8afgb PMID:18520350

37. Snowden JM, Raymond HF, McFarland W. Prevalence of seroadaptive behaviours of men who have sex with men, San Francisc0, 2004. Sex Transm Infect. 2009;85(6):469-76. http:// dx.doi.org/10.1136/sti.2009.036269 PMID:19505875

38. Vallabhaneni S, Li X, Vittinghoff E, Donnell D, Pilcher CD, Buchbinder SP. Seroadaptive practices: association with HIV acquisition among HIV-negative men who have sex with men. PLOS ONE. 2012;7(10):e45718. http://dx.doi.org/10.1371/ journal.pone.0045718 PMID:23056215

39. Rosenbrock R, Dubois-Arber F, Moers M, Pinell P, Schaeffer $D$, Setbon M. The normalization of AIDS in Western European countries. Soc Sci Med. 2000;50(11):1607-29. http://dx.doi. org/10.1016/S0277-9536(99)00469-4 PMID:10795967 